Rozprawy Komisji Językowej ŁTN, t. LXVII, 2019

ISSN 0076-0390; e-ISSN 2450-9310

https://doi.org/10.26485/RKJ/2019/67/9

Łesia Korol*

(D) https://orcid.org/0000-0002-4118-3291

\title{
NARODOWO-KULTUROWA I JEZZYKOWA TOŻSAMOŚĆ UCZNIÓW POLSKICH SZKÓŁ NA UKRAINIE
}

\author{
THE NATIONAL, CULTURAL, AND LINGUISTIC IDENTITY \\ OF POLISH SCHOOL STUDENTS IN UKRAINE
}

The young generation of the Poles living in Ukraine is multilingual. For the students of Polishlanguage schools in Ukraine, the Polish language performs not so much a communicative function, but a manifesting one, the latter being the factor of identification. The linguistic identity is perceived as a part of the ethnic/national identity.

Keywords: national identity, Polish language, Poles living in Ukraine, bilingualism

Słowa kluczowe: tożsamość narodowa, język polski, Polacy na Ukrainie, bilingwizm

Problematykę tożsamości narodowej od lat porusza się w różnego typu badaniach socjologicznych i socjolingwistycznych. Ogromne zainteresowanie budzi samoidentyfikacja Polaków poza granicami kraju, w szczególności zamieszkujących tzw. Kresy Wschodnie. Wraz z przemianami politycznymi i społecznymi zmienia się także sytuacja poszczególnych grup narodowościowych. Pociaga to za sobą zmiany w językach używanych przez społeczności wielonarodowościowe.

Przez cały okres powojenny polskie szkolnictwo było i nadal pozostaje podstawowym czynnikiem zapewniającym Polakom na Ukrainie utrzymanie języka ojczystego. Język młodego pokolenia Polaków na Ukrainie rzadko stawał się przedmiotem zainteresowania naukowców. Zajmowano się przede wszystkim ogólnym opisem polszczyzny kresowej, jej dialektu południowego

* Narodowy Uniwersytet Lwowski im. Iwana Franki, Wydział Filologiczny, Katedra Filologii Polskiej, ul. Uniwersytecka 1, 79000 Lwów; e-mail: korol_lesia@ukr.net. 
[Kurzowa, 1985; Rieger, 2002] lub prasy polskojęzycznej [Sojka-Masztalerz, 1999]. W ciagu ostatnich lat ukazało się jednak kilka artykułów poruszających temat kompetencji językowej oraz roli polszczyzny w życiu młodych użytkowników języka polskiego na Ukrainie Zachodniej [Zielińska, 2011; Geben, Zielińska, 2016]. Młode pokolenie Polaków mieszkających na Ukrainie jest wielojęzyczne, a języki, które oddziaływały na siebie w przeszłości, są nadal w kontakcie. Zmienia się jednak świadomość narodowościowa i językowa użytkowników.

Celem niniejszego opracowania jest określenie narodowo-kulturowej, w tym językowej, tożsamości uczniów polskich szkół na Ukrainie. Przedstawiam tu wyniki badań socjolingwistycznych, ukazujących współczesny stan świadomości językowej polskiej młodzieży uczniowskiej.

Obecnie na Ukrainie jest pięć szkół z polskim językiem nauczania: dwie we Lwowie (w obu uczy się ponad 600 uczniów), w Mościskach w obwodzie lwowskim (240 uczniów), w Strzelczyskach w obwodzie lwowskim (66 uczniów) i w Gródku w obwodzie chmielnickim (332 uczniów) ${ }^{1}$. Badania przeprowadzone zostały wśród uczniów ósmych, dziewiątych i dziesiątych klas (razem 236 osób). Materiał do opisu zebrano, posługując się metodą kwestionariuszową, metodą wywiadu (rozmowy z uczniami nagrywano z pomocą dyktafonu) oraz ekscerpcją uczniowskich tekstów pisanych.

Tożsamość narodowa jest zarówno kwestią filozoficzną, jak i językową. Jedną z cech przynależności do pewnej społeczności jest bowiem posługiwanie się tym samym językiem wewnątrz tej grupy. Pewność siebie i szacunek do samego siebie to podstawy rozwoju wszystkich społeczności. W związku z tym każda wspólnota, aby wierzyć w siebie, musi się określić, być pewna swojej tożsamości, mieć poczucie pokrewieństwa i ciagłości istnienia. Przynależność do społeczności etnicznej i narodowej określa się wspólnym modelem społeczno-kulturowym, który obejmuje wiele elementów, takich jak kultura (w najszerszym tego słowa znaczeniu), religia, historia, język, przestrzeń życiowa, świadomość wspólnoty i przynależności do społeczności, zorganizowanie społeczne i polityczne itp. Elżbieta Sękowska, badająca sposoby identyfikacji Polaków w Wielkiej Brytanii, wyodrębnia - jako podstawowe - następujące elementy: uczenie się i używanie języka polskiego, przynależność do polskiego Kościoła, korzenie polskie, utrzymywanie kontaktów z kolegami i krewnymi w Polsce, a nawet kuchnię polską [Sękowska, 1994, s. 126].

1 Badania zostały przeprowadzone w kilku etapach: we Lwowie w latach 2008-2010, w Mościskach, Strzelczyskach oraz Gródku w 2015 roku. 
Tożsamość kulturowa to jedna z odmian tożsamości społecznej (zbiorowej) należy pojmować ją jako względnie trwałą identyfikację pewnej grupy ludzi i pojedynczych jej członków z określonym układem kulturowym, tworzonym przez zespół idei, przekonań, poglądów, z konkretnymi zwyczajami i obyczajami, z danym systemem aksjologicznym i normatywnym. Owa identyfikacja powinna umacniać wewnętrzną jedność grupy i stanowić o jej specyfice. Jak piszą Marek Szczepański i Anna Śliz, tożsamość taką można wyrazić słowami: „Jesteśmy tacy, jacy jesteśmy, jesteśmy inni, a to, że jesteśmy inni, ma stanowić powód do dumy, a nie do zawstydzenia" [Szczepański, Śliz, 2010]. W literaturze przedmiotu spotykamy też określenia tożsamości regionalnej i - przez analogię - lokalnej. Są one szczególnymi przypadkami tożsamości społecznej (zbiorowej) i kulturowej, opartej na tradycji regionalnej (lokalnej), odnoszonej do wyraźnie zdefiniowanego i delimitowanego terytorium, regionu (miejsca), jego specyficznych cech społecznych, kulturowych (symbolicznych), gospodarczych czy nawet topograficznych, wyróżniających go spośród innych regionów (miejsc). W tym znaczeniu tożsamość regionalna bywa łączona, przynajmniej w niektórych przypadkach, z tożsamością etniczną (grupą etnograficzna, grupą etniczną).

Młode pokolenie Polaków na Ukrainie utrzymuje wyniesioną z domu znajomość wariantu regionalnego polszczyzny południowokresowej ${ }^{2}$ i uczy się w szkole języka polskiego oraz jest co najmniej bilingwalne. Klasyczną definicję bilingwizmu:

Posługiwanie się na co dzień przez daną grupę społeczną dwoma różnymi językami. Dwujęzyczność wytwarza się na terenach o mieszanym składzie etnicznym [Polański, 2003, s. 130]

uszczegóławiam do ujęcia Kingi Geben:

Umiejętność, w której zakładane jest jako minimum posługiwanie się dwoma językami na co dzień w taki sposób, by osoba używająca ich potrafiła w sytuacjach wymagających języka potocznego, porozumieć się w każdym z tych dwóch języków z innymi osobami znającymi tylko jeden z nich, w sposób dla tych osób zrozumiały, bez szczególnej pomocy gestów, mimiki lub środków paralingwistycznych, a także potrafiła odbierać wszystko, co do niej mówią inne osoby ze słuchu [Geben, 2003, s. 13].

Badani uczniowie używają na co dzień języka polskiego i ukraińskiego lub rosyjskiego. Identyfikację etniczną można określić na podstawie własnego poczucia tożsamości respondentów, a także badając postawy wobec konkretnych

2 Większość językoznawców skłonna jest uważać dialekty kresowe nie za dialekty w ścisłym rozumieniu tego terminu, lecz za odmiany/warianty regionalne (odmiany, którymi mówią wykształceni mieszkańcy miast różnych regionów). Ich status do 1939 roku był znacznie wyższy niż teraz, gdyż obecnie polszczyzna na tych terenach funkcjonuje jako język polonijny (czyli język osób znajdujących się poza granicami kraju). 
wartości kulturowych, takich jak znajomość i używanie języka czy uczestnictwo w organizacjach etnicznych. Samoświadomość - jako rozumienie siebie i własnego funkcjonowania w społeczeństwie oraz kulturze - jest podstawą (czy też swoistym punktem wyjściowym) w złożonym procesie budowania tożsamości jednostkowej. Pojęcie tożsamości nieodłącznie wiąże się z kwestiąjęzyka. Według Jerzego Jarosława Smolicza w polskiej kulturze język rodzimy ma (miał) status wartości centralnej (do takich podstawowych wartości badacz zalicza obecnie również katolicyzm) [Smolicz, 1990, s. 77-91].

Jak pisze Wojciech Hofmański:

Język natywny nie tylko determinuje myślenie, ale też buduje kulturę - tworzy więc rozległą sieć manifestującej się samoświadomości. Tak jednostkowej, jak i zbiorowej [Hofmański, 2015, s. 27].

Jednak zdaniem badacza tym, co wyraźnie komplikuje binarny układ język - tożsamość, jest multilingwizm.

Zdecydowana większość osób badanych pochodzi z rodzin polskich (56\%) i mieszanych polsko-ukraińskich (26\%) lub polsko-rosyjskich (4\%), jedna osoba $\mathrm{z}$ rodziny polsko-bułgarskiej i jedna z polsko-niemieckiej. Korzenie polskie ma $11 \%$, ponieważ ktoś z dziadków jest/był Polakiem. Pozostałe 2\% zaznaczyło, że pochodzą z rodzin ukraińskich. Większość ankietowanych to młodzież z rodzin inteligenckich (rodzice to osoby z wyższym wykształceniem: nauczyciele, biznesmeni, lekarze, prawnicy itp.), druga grupa to młodzież wywodząca się z rodzin robotniczych (rodzice reprezentują różne zawody, np. elektryk, malarz, pielęgniarka, budowniczy, barman itp. i różny poziom wykształcenia - od zawodowego do średniego).

Badana młodzież to osoby polilingwalne - znają bowiem kilka języków. Oprócz języka polskiego (100\% ankietowanych oświadczyło, że mają dobrą znajomość tego języka w mowie i piśmie) najczęściej deklarują dobrą znajomość języka ukraińskiego (89\% - dobra w mowie i piśmie, 11\% - ogólna znajomość języka) i rosyjskiego (23\% - dobra w mowie i piśmie, $56 \%$ - dobra w mowie, $11 \%$ - ogólna znajomość języka). Oprócz tych języków uczniowie wymienili język angielski (27\% deklaruje dobrą znajomość w mowie i piśmie, 46\% ogólną znajomość języka), niemiecki (15\% - ogólna znajomość języka), serbski, słowacki (po jednej osobie z ogólną znajomością języka).

Język w społeczeństwie spełnia funkcję komunikatywną i poznawczą, a także jest środkiem identyfikacji społecznej i osobowej [Geben, 2003, s. 13]. Między językiem a społeczeństwem zachodzi ścisły związek, który wyraża się w sposobie funkcjonowania języka. Jednym z problemów badawczych we współczesnej 
socjolingwistyce jest kwestia świadomości językowej. Pojęcie świadomości językowej jest różnie definiowane przez badaczy. W niniejszym artykule przyjęto definicję pojęcia świadomości językowej stosowaną w badaniach socjolingwistycznych, głoszącą, że:

Pojęcie społecznej świadomości językowej określić można szeroko jako całość żywotnych w społeczeństwie - lub grupie społecznej - sądów i wyobrażeń związanych z językiem w ogóle, czyli z rozmaitymi zjawiskami języka oraz jego funkcjonowaniem [Dawlewicz, 2000, s. 28].

Pytania ankiety w dużej mierze dotyczyły postaw i zachowań młodzieży wobec języka polskiego, zakresu stosowania oraz stosunku młodzieży do wariantu regionalnego polszczyzny południowokresowej.

Jak już wspomniano, dla uczniów polskich szkół w codziennej komunikacji ważne są trzy języki: polski, ukraiński i rosyjski. W ramach komunikacji językowej między członkami omawianej grupy społecznej nie we wszystkich sytuacjach te języki moga jednakowo funkcjonować i prawdopodobnie mają różny zakres użycia. Jak pokazują odpowiedzi na pytanie: „W jakich sytuacjach używa Pan/Pani języka polskiego (proszę zaznaczyć wszystkie przypadki, które dotyczą Pana/Pani): w rozmowie z rodzicami i rodzeństwem; w rozmowach prywatnych (z przyjaciółmi, krewnymi); w kontaktach oficjalnych (szkoła, organizacje polonijne); inne sytuacje (proszę wymienić)", na przykład w rozmowie z rodzicami i rodzeństwem oraz w kontaktach oficjalnych (szkoła, organizacje polonijne) najczęściej używa się języka polskiego (odpowiednio 65\% i 95\%), ale już w rozmowach prywatnych (z przyjaciółmi), nawet na przerwach w szkole często używa się języka ukraińskiego lub rosyjskiego (65\%) i to dotyczy nie tylko dzieci pochodzących z rodzin mieszanych. Dla większości uczniów szkół polskich (78\%), zgodnie z ich własną deklaracja, język polski jest językiem rodzimym (ojczystym), przyswojonym jako pierwszy. Jednak często obok polskiego wskazują też na język ukraiński lub rosyjski. Liczne są też przypadki, kiedy osoba uważa za rodzimy język polski, ale jako pierwszy przyswoiła język ukraiński (27\%) lub rosyjski (8\%).

Różnice między polszczyzną używaną w Polsce i na Ukrainie wyraźnie dostrzega $92 \%$ badanych osób i wszyscy oni uważają że dotyczą one głównie wymowy i akcentu. 22\% respondentów twierdzi, że różnice ujawniają się w odmianie niektórych wyrazów. W niektórych wypadkach (7\%) wskazano też słownictwo. Na ogół nieuświadamiane są różnice w zakresie składni. Niektórzy ankietowani próbowali nawet uzasadnić swój wybór w ankiecie (chociaż niezbyt precyzyjnie). Na przykład na prośbę o podanie przykładów różnic między polszczyzną używaną 
w Polsce i we Lwowie, uzyskano odpowiedzi: $W$ Polsce bardziej prawidtowy akcent, we Lwowie - zmieszczony; Do czasowników polskich dodają ukraińskie lub rosyjskie końcówki - w Polsce „,zrobiłem”, „zrobiteś”, we Lwowie - „zrobit”, „,zrobit”; Gwary i wielka ilość ukrainców”, użwajacych odmiane języka polskiego; Używaja prostych nieciekawych stów; Niektórzy mówia zamiast litery , t" ,l"- bylem, chodzilem ${ }^{4}$; Postugiwanie się rusyzmami i ukrainizmami.

Uczniowie mieli również odpowiedzieć na pytanie, jakiej odmiany języka polskiego, ich zdaniem, powinni używać Polacy na Ukrainie. 49\% ankietowanych stwierdziło, że niezależnie od sytuacji komunikatywnej trzeba posługiwać się językiem ogólnopolskim (literackim), 9\% wybrało polszczyznę „lokalną”, a 42\% opowiedziało się za użyciem polszczyzny „lokalnej” lub języka ogólnopolskiego - w zależności od sytuacji. Niektórzy z tych ostatnich próbowali uzasadnić, w jakich sytuacjach należy używać danej odmiany. Na przykład: Na biesiadzie literackiej - ,literackiego”, z kolegami - , lokalnego” [języka], a nawet Kto jak umie i chce, ale trzeba dążć do lepszego języka.

Istotnym czynnikiem powodującym większą trwałość języka polskiego na tych terenach są instytucje zajmujące się propagowaniem poprawności językowej. Polszczyznę ogólną uczeń opanowuje w sposób zorganizowany w szkole, a w sposób niezorganizowany na przykład dzięki udziałowi w polskich organizacjach młodzieżowych, programom telewizyjnym i radiowym nadawanym w języku polskim, czytaniu książek i prasy polskojęzycznej.

Zdecydowana większość - 91\% - wskazuje na szkołę jako podstawową instytucję zajmującą się propagowaniem języka polskiego, 84\% przypisuje tę ważną funkcję również Kościołowi katolickiemu. Stosunkowo niewielu uczniów - 23\% - wskazuje na rolę polskiej prasy, radia i telewizji, a $12 \%$ na organizacje polskie (nie zaznaczając, o które organizacje chodzi). Duże znaczenie dla przyswajania i doskonalenia języka ma czytanie polskiej prasy i książek. Kontakty z prasą i literaturą polską, deklarowane przez respondentów, dają na ogół obraz optymistyczny: $32 \%$ ankietowanych czyta książki i gazety systematycznie, $45 \%$ często, $19 \%$ rzadko, $2 \%$ sporadycznie a dwie osoby zaznaczyły, że wcale nie czytają. Wśród prasy najczęściej wymieniano popularne magazyny młodzieżowe: „Brawo”, „Dziewczynę”, „Popcorn”, „Przyjaciółkę”, „Panią Domu” (które mię-

3 Zachowano pisownię oryginalna.

4 Prawdopodobnie respondentowi chodzi o wymowę spółgłoski przedniojęzykowej dziąsłowej [1] zamiast tylnojęzykowej [u].

5 Używając wyrazu biesiada, uczeń prawdopodobnie miał na myśli rozmowę-od ukraińskiego бесiдa lub rosyjskiego беседa, które to wyrazy mają takie właśnie znaczenie, a nie biesiadę - wystawne przyjęcie. Mamy tu do czynienia $\mathrm{z}$ homonimią międzyjęzykową. 
dzy innymi można było kupić w szkole) oraz czasopisma: „Gazetę Lwowską”, „Kurier Galicyjski”, „Źródło” i „Radość Wiary”. Wymienione w ankiecie książki najczęściej należały do lektur szkolnych.

Język polski dociera również do odbiorców za pośrednictwem telewizji i rozgłośni radiowych. Programy polskiej telewizji ogląda 64\% ankietowanych i uzasadnia to następująco: Przez TV wzbogacamy swój zapas słowny $i$ jest ciekawa; Dlatego, że jest z Polski i w języku polskim; Dlatego, że lubię ogladać filmy w języku polskim; Dlatego, że sa mite, przyjemne programy, na odmiane od ukraińskiej reklama jest o wiele przyjemniejsza; Dlatego, że pokazuja ciekawe programy; Dlatego, że mi się podoba; Bo jestem Polka; Żeby stuchać języka ojczystego; Dlatego, że jest w niej [telewizji] obecny język polski; Dlatego, że jestem Polakiem i kocham swoja Ojczyznę. Polskiej telewizji nie ogląda 30\% respondentów, ponieważ nie ma takich możliwości technicznych (Nie mamy anteny satelitarnej; Nie mam programów na kablówce) lub nie ma na to czasu (6\%).

Polskiego radia słucha 52\% ankietowanych, przy czym, jak sami deklarują, motywy, którymi kierują się przy wyborze polskiej rozgłośni radiowej, wiążą się przede wszystkim z językiem (np.: Lepiej poznaje język polski; Jest w nim [w radiu] współczesny język polski; Bojestem Polakiem), w mniejszym zaś stopniu z muzyką współczesną i informacją (np.: Leci tam dobra muzyka; Podoma mi się, że piosenki stamtad; Lubię polskie piosenki; Tam sa ciekawe tematy). Polskiego radia nie słucha $48 \%$ uczniów - powody tego to: niesłuchanie radia wcale $-25 \%$, brak czasu na to $-6 \%$, reszta nie uzasadniła swojego wyboru.

Elementem tożsamości społecznej bywa też tożsamość kulturowa, która, jak pisze Hanna Komorowska, określana bywa zazwyczaj przez tradycję i styl życia, przybliżają ją jednak również tak zwane wartości rdzenne, kluczowe dla danej zbiorowości [Komorowska, 2017, s. 9]. Kolejne pytania, które zadano respondentom, dotyczyły ich udziału w życiu religijnym oraz motywów wyboru liturgii w języku polskim lub ukraińskim. 97\% ankietowanych uczniów chodzi do kościoła, uczestniczy we mszy i modli się po polsku. Natomiast 9\% deklaruje, że może też uczestniczyć w nabożeństwach w języku ukraińskim. Najważniejszy motyw wyboru Kościoła dla respondentów to rodzinne tradycje religijne $(85 \%)$, a w drugiej kolejności język, w którym odprawiane jest nabożeństwo (65\%). Ważna jest także możliwość spotkania w kościele znajomych Polaków (42\%), dalej znalazły się odpowiedzi, w których podkreśla się przywiązanie do pieśni religijnych. Ankietowana młodzież wykazuje duże przywiązanie do polskich tradycji narodowych i świąt Bożego Narodzenia czy Wielkanocy. Wszyscy respondenci wypowiedzieli się za utrzymaniem tradycji narodowych i kościelnych. 
Podsumowując wyniki badań nad świadomościąjęzykową uczniów polskich szkół na Ukrainie, można stwierdzić, że młodzież ta jest bilingwalna i przywiązana do języka ojczystego. Młode pokolenie Polaków nie ma negatywnego stosunku do wariantu regionalnego polszczyzny południowokresowej, ale przekonane jest, że można go używać tylko w określonych sytuacjach komunikacyjnych (w kontaktach nieoficjalnych). Młodzi respondenci zdają sobie sprawę z odmienności tej polszczyzny. Ważne dla uczniów jest też utrzymanie tradycji narodowych i kościelnych.

\section{BIBLIOGRAFIA}

Dawlewicz Mirosław, 2000, Stownictwo socjolektu młodzieży polskiego pochodzenia w Wilnie, Dom Wydawniczy Elipsa, Warszawa.

Geben Kinga, 2003, Świadomość i kompetencja językowa a warstwy leksykalne $w$ idiolektach młodzieży polskiego pochodzenia na Wileńszczyźnie, Dom Wydawniczy Elipsa, Warszawa.

Geben Kinga, ZielińsKa Maria, 2016, Sytuacja socjolingwistyczna a kompetencja leksykalno-słowotwórcza młodzieży ze szkót polskich z Solecznik (Litwa) i Gródka (Ukraina), „Prace Filologiczne”, t. LXIX, s. 155-168.

HOFMAŃski Wojciech, 2015, Język-tożsamość - komunikacja, „Slavia Occidentalis", t. 72(1), s. 27-37.

KomorowsKa Hanna, 2017, Język a tożsamość. Język pierwszy, drugi i obcy a sukcesy i niepowodzenia szkolne, „Neofilolog”, $\mathrm{nr}$ 49/1, s. 7-24.

Kunzowa Zofia, 1985, Polszczyzna Lwowa i kresów południowo-wschodnich do 1939 roku, Państwowe Wydawnictwo Naukowe, Warszawa-Kraków.

PolaŃSKI Kazimierz, red., 2003, Encyklopedia językoznawstwa ogólnego, Zakład Narodowy im. Ossolińskich, Wrocław.

RIEGER Janusz, 2002, Język mniejszości - z problematyki badawczej w odniesieniu do polszczyzny na Wschodzie i języka ukraińskiego w Polsce, w: tegoż, red., Język mniejszości w otoczeniu obcym, Wydawnictwo Naukowe Semper, Warszawa, s. 9-16.

SŁ̨KOwSKA Elżbieta, 1994, Język zbiorowości polonijnych w krajach anglojęzycznych. Zagadnienia leksykalno-stowotwórcze, Wydawnictwa Uniwersytetu Warszawskiego, Warszawa.

Smolicz Jerzy Jarosław, 1990, Kultura i nauczanie w społeczeństwie wieloetnicznym, Państwowe Wydawnictwo Naukowe, Warszawa. 
SojKa-MaszTalerz Helena, 1999, Niektóre zjawiska stowotwórcze i leksykalne we współczesnej polszczyźnie lwowian, w: J. Rieger, red., Studia nad polszczyzna kresowa, t. IX, Wydawnictwo Naukowe Semper, Warszawa, s. 237-242. SzCZEPAŃSKi Marek, Ślzz Anna, 2010, Dylematy regionalnej tożsamości. Przypadek Górnego Śląska, „Nowe Zagłębie”, nr 6, s. 17-20.

ZIELIŃSKa Maria, 2011, Rola polszczyzny w życiu młodych użytkowników języka polskiego na Ukrainie Zachodniej w: I. Kotuna, P. Nowak, red., Język. Komunikacja. Informacja. Polityka językowa w Europie Środkowo-Wschodniej, t. 6, Wydawnictwo Sorus, Poznań, s. 127-134.

\title{
Eesia Korol
}

\section{NARODOWO-KULTUROWA I JĘZYKOWA TOŻSAMOŚĆ UCZNIÓW POLSKICH SZKÓŁ NA UKRAINIE}

\begin{abstract}
Streszczenie
W artykule przedstawiona została obecna sytuacja językowa w środowisku uczniów pięciu szkół ogólnokształcących na Ukrainie z polskim językiem nauczania. Uczniowie utrzymują wyniesioną z domu regionalną polszczyznę południowokresową oraz uczą się w szkole języka polskiego. Młode pokolenie Polaków mieszkających na Ukrainie jest wielojęzyczne. Badania socjolingwistyczne pokazują że dla uczniów polskich szkół w codziennej komunikacji ważne są trzy języki: polski, ukraiński i rosyjski. Młodzi Polacy są przywiązani do języka polskiego. Nie ma w nich negatywnego nastawienia do jego regionalnego wariantu - jednak są przekonani, że można go używać tylko w niektórych sytuacjach komunikacyjnych (nieoficjalnych). Podsumowując wyniki badania, można argumentować, że polska młodzież na Ukrainie identyfikuje się jako odrębna grupa. Język polski pełni w jej przypadku nie tylko funkcję komunikacyjną, ale też manifestacyjną, przy czym ta druga jest faktycznym czynnikiem kształtowania tożsamości. Dlatego tożsamość językowa jest postrzegana jako część tożsamości etnicznej/narodowej. Ważnym elementem przynależności Polaków na Ukrainie do narodu polskiego jest też członkostwo w Kościele katolickim oraz przestrzeganie i zachowanie polskich tradycji ludowych i religijnych.
\end{abstract}

\section{THE NATIONAL, CULTURAL, AND LINGUISTIC IDENTITY OF POLISH SCHOOL STUDENTS IN UKRAINE}

\section{Summary}

This article seeks to explore the current language situation among the students of Polishlanguage schools in Ukraine (presently, there are five comprehensive schools with Polish as a language of instruction in Ukraine). Students are speakers of the regional versions of the Polish language which they speak at home, whereas at school they study the general Polish language. In addition, the young generation of the Poles living in Ukraine is multilingual. The sociolinguistic 
research demonstrates that three languages are important for Polish-language school students in everyday communication and society: Polish, Ukrainian and Russian. The young generation of Poles is tied to the Polish language. They have no negative attitude to the regional versions of the Polish language, but students are convinced that it can be used only in certain communicative situations (informal). Based on the results of the study, it can be argued that Polish youth in Ukraine identify themselves as a separate group. For them, the Polish language performs not so much a communicative function, but a manifesting one, the latter being the factor of identification. For this reason linguistic identity is perceived as a part of their ethnic/national identity. The Poles of Ukraine consider that their affiliation to the Catholic Church is an important element of their unity with the Polish people, as well as the observance and preservation of Polish folk and religious traditions. 